\title{
Multifunctionality of the Enzyme Involved in the 2,3-Diphosphoglycerate Metabolism of Pig Erythrocytes
}

\author{
Ryuzo Sasaki, Koji Ikura, Hiroshi Narita and Hideo Chiba \\ Department of Food Science and Technology, Faculty of Agriculture, \\ Kyoto University, Kyoto 606, Japan \\ Received June 21, 1976
}

\begin{abstract}
In a continuing study of the enzymes involved in the 2,3-diphosphoglycerate metabolism of mammalian erythrocytes, we report that 2,3-diphosphoglycerate in pig erythrocytes is probably metabolized by one multifunctional enzyme.

Diphosphoglyceromutase, 2, 3-diphosphoglycerate phosphatase, and phosphoglyceromutase were simultaneously purified from pig erythrocytes. Three fractions (peaks I, II, and III) which had all three activities in different ratios were obtained by column chromatography. Peak I was extremely rich in phosphoglyceromutase, containing more than $90 \%$ of the total activity of this enzyme. In contrast, peak III was active in metabolizing 2, 3-diphosphoglycerate, containing about $95 \%$ of both the diphosphoglyceromutase and the 2, 3-diphosphoglycerate phosphatase activity. It seems likely that peak I functions as phosphoglyceromutase and that peak III functions in the 2, 3-diphosphoglycerate metabolism.

The homogeneity of peak III was established by disc gel electrophoresis in the presence and the absence of sodium dodecyl sulfate, as well as by ultracentrifugation. The three activities of peak III were lost at the same rate on thermal inactivation. These results indicate that the two enzyme activities for metabolizing 2, 3-diphosphoglycerate, which were believed to be due to different proteins, are attributable to one protein, along with some phosphoglyceromutase activity. The diphosphoglyceromutase activity of this protein was inhibited by the product, 2,3-diphosphoglycerate, as well as by hydroxypyruvate phosphate, 2-phosphoglycolate, inorganic phosphate, and bisulfite. The 2,3-diphosphoglycerate phosphatase activity was enhanced by 2-phosphoglycolate and hydoxypyruvate phosphate, and by the coexistence of chlorine ion and bisulfite, while it was inhibited by monophosphoglycerates. The native peak III protein had a molecular weight of 59,000 as determined by equilibrium centrifugation. Disc gel electrophoresis in the presence of sodium dodecylsulfate yielded a single protein band with a molecular weight of 28,000 , indicating that this protein was composed of two subunits with a similar molecular weight.

Occurrence of multifunctional proteins in pig erythrocytes is compared with that in human erythrocytes from the standpoint of the universal existence of such proteins.
\end{abstract}

2, 3-Diphosphoglycerate $\left(2,3 \mathrm{DPG}^{*}\right)$ is the most abundant organic-acid-soluble phosphate in the erythrocytes of man and many other mammalian species. ${ }^{1,2)}$ Several biological functions besides the primary function as an essential reactant in the PGA mutase reaction (Eq. 1) have been assigned to 2,3DPG in human erythrocytes, ${ }^{3 \sim 12}$ and much attention has been focused on the regulation of levels for

* Abbreviations: 2,3DPG, 2, 3-diphosphoglycerate; 1,3DPG, 1, 3-diphosphoglycerate; 3PGA, D-3phosphoglycerate; 2PGA, DL-2-phosphoglycerate; HPAP, hydroxypyruvate phosphate; PGA mutase, phosphoglyceromutase; DPG mutase, diphosphoglyceromutase. this compound. Two enzymes, DPG mutase (Eq. 2) and 2, 3DPG phosphatase (Eq. 3), are directly involved in the 2, 3DPG metabolism of erythrocytes. It was believed that

3-phosphoglycerate $+2,3$-diphosphoglycerate

$$
\begin{aligned}
& \text { 2-phosphoglycerate }+2,3 \text {-diphos- } \\
& \text { phoglycerate }
\end{aligned}
$$

Phosphoglyceromutase (EC 2. 7. 5.3) 3-phosphoglycerate- 1, 3-diphosphoglycerate

$\longrightarrow$ 3-phosphoglycerate $+2,3$-diphosphoglycerate 
Diphosphoglyceromutase (EC 2. 7. 5. 4)

2, 3-diphosphoglycerate

$\longrightarrow$ 3-phosphoglycerate + inorganic

phosphate

2, 3-Diphosphoglycerate phosphatase (EC

3. 1.3.13)

these two enzymes were different protein molecules because of the irreversible character of the reactions catalyzed. Recently, however, we have reported evidence that both DPG mutase and 2,3DPG phosphatase activities in human erythrocytes are attributable to one protein which has the PGA mutase activity. ${ }^{13,14)}$ Subsequently papers supporting this conclusion have appeared from other laboratories. ${ }^{15,16)}$ Human erythrocytes have three kinds of multifunctional proteins which contain the three enzyme activities in different ratios. ${ }^{13)}$ One of these kinds (peak I) is high in PGA mutase activity and probably functions in the main pathway of glycolysis, while another (peak III) has high DPG mutase and 2,3DPG phosphatase activities, about $95 \%$ of their total activities in the erythrocytes. The ratio of the three enzyme activities of peak II is intermediate to those of I and III. It is evident from the low activities of the enzymes metabolizing 2, 3DPG in the peak II protein that this peak contributes little to the 2,3DPG metabolism. Chemical modification experiments have shown that the three enzyme activities of peak III protein, which is chiefly responsible for the 2,3DPG metabolism, are manifested at a common active site. Based on these results, a new regulatory mechanism has been proposed for the 2,3DPG metabolism in human erythrocytes. ${ }^{14,}$

In view of the physiological implications if such multifunctional proteins exist universally in living cells, acting as tools for metabolic regulation, we have undertaken to investigate the enzymes involved in the 2,3DPG metabolism of other mammals. This report describes the purification of the protein metabolizing $2,3 \mathrm{DPG}$ in pig erythrocytes to homogeneity, and furnishes some evidences for the universality of multifunctional proteins.

\section{MATERIALS AND METHODS}

Chemicals and enzymes. 2,3DPG, 3PGA DL* glyceraldehyde-3-phosphate, glyceraldehyde-3-phosphate dehydrogenase, and enolase (Boehringer Mannheim $\mathrm{GmbH}$ ), Sephadex G-100, DEAE-Sephadex $\mathrm{A}-50$, and CM-Sephadex C-50 (Pharmacia Fine Chemicals), DL- $\alpha$-glycerophosphate and $\beta$-glycerophosphate (Merck), bovine serum albumin, ovalbumin, $\alpha$-chymotrypsinogen, and cytochrome c (Schwarz) Mann), NAD ${ }^{+}$(Kohjin) and hydroxylapatite (Clarkson Chemical Co.), HPAP (Calbiochem), 2-phosphoglycolate (Sigma), ampholine (LKB), and DEAE-cellulose (Serva) were purchased from the indicated sources. Other chemicals used were of reagent grade. 2-PGA was synthesized by the oxidation of $\beta$-glycerophosphate according to the method of Kiessling, ${ }^{17)}$ then purified on a Dowex-1 $\mathrm{Cl}^{-}$column as described by Bartlett. ${ }^{18)}$ 1, 3DPG was prepared as described previously. ${ }^{193}$ Yeast PGA mutase was purified and crystallized as described previously. ${ }^{12,20)}$

\section{Enzyme assays}

$D P G$ mutase, 2, 3DPG phosphatase and $P G A$ mutase. The activities of these enzymes were measured as described previously. ${ }^{13}$ )

In all instances, one unit of enzyme activity is defined as the amount of enzyme which catalyzes the conversion of $1 \mu$ mole of substrate to product per min under the conditions stated. Specific activity is expressed as units per $\mathrm{mg}$ of protein.

Isoelectric focusing. Conditions for isoelectric focusing were as described previously ${ }^{13)}$ except that an ampholine solution ( $\mathrm{pH}$ range of 3.5 to 10 ) and a $5 \mathrm{~mm}$ Tris-HCl buffer $\mathrm{pH} 7.5$ containing $0.1 \mathrm{~mm}$ EDTA and $5 \mathrm{~mm} \beta$-mercaptoethanol (buffer $\mathrm{A}$ ) were used. Electrofocusing was carried out for $12 \mathrm{hr}(400 \mathrm{~V}, 0.6 \mathrm{~mA})$.

Polyacrylamide gel electrophoresis. Polyacrylamide gel electrophoresis was carried out according to the procedure of Davies ${ }^{22)}$ and that of Weber and Osborn ${ }^{23)}$ in the presence of sodium dodecylsulfate. Conditions were as described previously ${ }^{1.37}$ except that buffer $\mathrm{A}$ was used and a current of $8 \mathrm{~mA}$ per gel was applied for $3.5 \mathrm{hr}$ in the presence of sodium dodecylsulfate.

Ultracentrifugation. Ultracentrifugation was carried out in a Beckman model $\mathrm{E}$ analytical ultracentrifuge at $20^{\circ} \mathrm{C}$. Sedimentation velocity experiments were performed with a double-sector cell. The sedimentation equilibrium experiments were performed according to the meniscus-depletion method of Yphantis. ${ }^{24)}$

Protein concentration. Protein was determined by measuring the absorbance at $280 \mathrm{~nm}$. Its concentration was calculated from the absorbance at $280 \mathrm{~nm}$ based on the value $E_{280 \mathrm{~nm}}^{1 \%}=10$. 


\section{RESLLTS}

\section{Purification of enzymes}

Table $I$ is a summary of the procedure used in the purification of the three enzymes. All procedures were carried out at $0 \sim 4^{\circ} \mathrm{C}$.

Hemolysate. Slaughter-house blood of pigs was collected in a plastic bottle which contained $140 \mathrm{ml}$ of $3.5 \%$ trisodium citrate per liter of blood. Purification of the enzymes was begun using $1750 \mathrm{ml}$ of the blood. Hemolysates of the pig erythrocytes were prepared as described previously for human erythrocytes. ${ }^{13 ;}$

Bulk separation on DEAE-cellulose. The hemolysates were mixed with $56 \mathrm{~g}$ of DEAEcellulose previously equilibrated with buffer A. After stirring the mixture for $3 \mathrm{hr}$, the cellulose with the absorbed enzymes was filtered on a Buchner funnel and washed with $1000 \mathrm{ml}$ of buffer A containing $0.05 \mathrm{M} \mathrm{KCl}$. Then, the enzymes were eluted by washing the cellulose with $1200 \mathrm{ml}$ of buffer A containing $0.35 \mathrm{M}$ $\mathrm{KCl}$. The proteins in the eluate was precipitated by adding solid ammonium sulfate to $75 \%$ saturation. Ammonium sulfate fractionation. The activity.

Table I. Summary of Enzyme Purification

DPG mutase and 2, 3 DPG phosphatase activities were assayed with Assays $I^{13}$ The activity of the hemolysates was measured after dialysing against buffer $\mathrm{A}$. 2, $3 \mathrm{DPG}$ ase =2, 3 DPG phosphatase.

\begin{tabular}{|c|c|c|c|c|c|c|c|c|c|c|}
\hline \multirow[t]{2}{*}{ Fractions } & \multirow[t]{2}{*}{ Protein } & \multicolumn{3}{|c|}{ Activity } & \multicolumn{3}{|c|}{ Specific activity } & \multicolumn{3}{|c|}{ Yield } \\
\hline & & $\begin{array}{l}\text { DPG } \\
\text { mutase }\end{array}$ & $\begin{array}{c}2,3 \mathrm{DPG} \\
\text { ase }\end{array}$ & $\begin{array}{l}\text { PGA } \\
\text { mutase }\end{array}$ & $\begin{array}{l}\mathrm{DPG} \\
\text { mutase }\end{array}$ & $\begin{array}{c}2,3 \mathrm{DPG} \\
\text { ase }\end{array}$ & $\begin{array}{l}\text { PGA } \\
\text { mutase }\end{array}$ & $\begin{array}{l}\text { DPG } \\
\text { mutase }\end{array}$ & $\begin{array}{c}2,3 \mathrm{DPG} \\
\text { ase }\end{array}$ & $\begin{array}{l}\text { PGA } \\
\text { mutase }\end{array}$ \\
\hline & $\mathrm{mg}$ & \multicolumn{3}{|c|}{ units } & \multicolumn{3}{|c|}{ units/mg protein } & \multicolumn{3}{|c|}{$\%$} \\
\hline Hemolysate & 292000 & 840 & 103 & 4820 & 0.0028 & 0.0003 & 0.0165 & 100 & 100 & 100 \\
\hline $\begin{array}{l}\text { DEAE-Cellulose } \\
\left(\mathrm{NH}_{4}\right)_{2} \mathrm{SO}_{4}\end{array}$ & 8500 & 800 & 98 & 4760 & 0.094 & 0.0115 & 0.56 & 95.2 & 95.1 & 98.1 \\
\hline $\begin{array}{l}\text { fractionation } \\
\text { DEAE-Sephadex }\end{array}$ & 3600 & 720 & 90 & 4390 & 0.200 & 0.025 & 1.22 & 85.7 & 87.4 & 91.1 \\
\hline $\begin{array}{r}\text { First peak } \\
\text { (peak I) }\end{array}$ & 535 & 1.1 & 0.52 & 3285 & 0.002 & 0.001 & 6.17 & 0.13 & 0.51 & 68.2 \\
\hline Second peak & 457 & 560 & 66 & 265 & 1.23 & 0.144 & 0.58 & 66.7 & 64.1 & 5.5 \\
\hline $\begin{array}{l}\text { Sephadex } G-100 \text { of } \\
\text { the second peak }\end{array}$ & 42 & 247 & 36 & 143 & 5.87 & 0.856 & 3.4 & 29.4 & 35.0 & 3.0 \\
\hline Hydroxylapatite & & & & & & & & & & \\
\hline Peak II & 3.5 & 3.65 & 1.95 & 9.2 & 1.05 & 0.562 & 2.63 & 0.43 & 1.9 & 0.19 \\
\hline Peak III & 7.8 & 89 & 13.2 & 41.3 & 11.4 & 1.7 & 5.3 & 10.6 & 12.9 & 0.86 \\
\hline $\begin{array}{l}\text { CM-Sephadex of } \\
\text { Peak I }\end{array}$ & 43 & 0.47 & 0.42 & 1420 & 0.0108 & 0.005 & 33.1 & 0.05 & 0.21 & 29.5 \\
\hline
\end{tabular}

precipitate was dissolved in $510 \mathrm{ml}$ of buffer $\mathrm{A}$. To $570 \mathrm{ml}$ of the solution was added $84 \mathrm{~g}$ of solid ammonium sulfate. The resulting suspension was centrifuged, and the pellet obtained was discarded. The proteins in the supernatant $(600 \mathrm{ml})$ were precipitated by adding $170 \mathrm{~g}$ of solid ammonium sulfate. The three enzyme activities, DPG mutase, 2, 3DPG phosphatase, and PGA mutase, were recovered in this fraction with an excellent yield.

Chromatography on DEAE-Sephadex. The precipitate was dissolved in and dialysed against buffer $\mathrm{A}$. The dialysed solution was chromatographed on a DEAE-Sephadex A-50 column $(4.8 \times 30 \mathrm{~cm})$ equilibrated with buffer A. Protein was eluted from the column by a $4000-\mathrm{ml}$ linear gradient of $\mathrm{KCl}$ ranging from 0 to $0.65 \mathrm{M} \mathrm{KCl}$ in buffer A. Figure 1 shows a typical elution profile of the three enzyme activities and proteins. Two peaks having the three activities in different ratios appeared. The first peak, termed peak I, contained the bulk of the PGA mutase activity and a small part of the DPG mutase and 2,3DPG phosphatase activities. A great part of the latter two activities was found in the second peak, along with a small part of the PGA mutase 


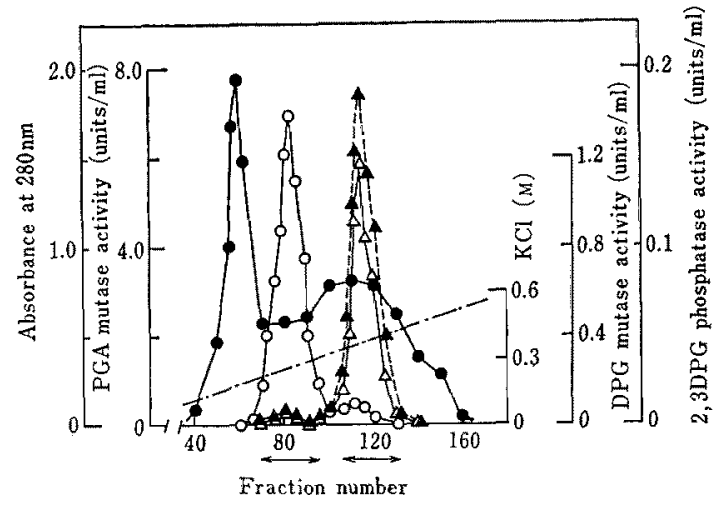

FIG. 1. Elution Profile from DEAE-Sephadex.

- - absorbance at $280 \mathrm{~nm} ; \triangle-\triangle$, DPG mutase; A--A, 2, 3DPG phosphatase: $\bigcirc-0$, PGA mutase; - -, $\mathrm{KCl}$ concentration.

Activities are expressed as units $/ \mathrm{ml}$. $1.56 \mathrm{~g}$ of the protein purified by ammonium sulfate fractionation was applied. Fractions were $20 \mathrm{ml}$. The flow rate was $3 \mathrm{ml} / \mathrm{min}$. The horizontal lines with arrow heads indicate fractions pooled after elution. Active fractions eluted early were designated as peak. I. DPG mutase and 2,3DPG phosphatase activities were assayed with Assays $I^{13}$

Sephadex G-100 chromatography. The enzymes in the second peak were further purified because this peak contained most of the enzyme activities which metabolized 2, 3DPG. Protein in the second peak was precipitated by adding solid ammonium sulfate to $75 \%$ saturation, then collected by centrifugation and dissolved in a minimum volume of buffer $A$. After removal of insoluble materials by centrifugation, the clear supernatant was applied to a Sephadex $\mathrm{G}-100$ column $(1.4 \times 93 \mathrm{~cm})$ equilibrated with buffer $\mathrm{A}$, and the column was developed with the same buffer. As shown in Fig. 2, the three enzyme activities were found in the same elution volume. Protein in the active fractions was precipitated by adding solid ammonium sulfate to $75 \%$ saturation.

\section{Hydroxylapatite chromatography. The} precipitate was dissolved in and dialysed against $10 \mathrm{~mm}$ potassium phosphate buffer $\mathrm{pH}$ 6.9 containing $0.1 \mathrm{~mm}$ EDTA and $5 \mathrm{~mm} \beta$ mercaptoethanol. The dialysed solution was added to a hydoxylapatite column $(1.2 \times 5.5$ $\mathrm{cm}$ ) equilibrated with the same buffer. The column was developed with a $100 \mathrm{ml}$ linear

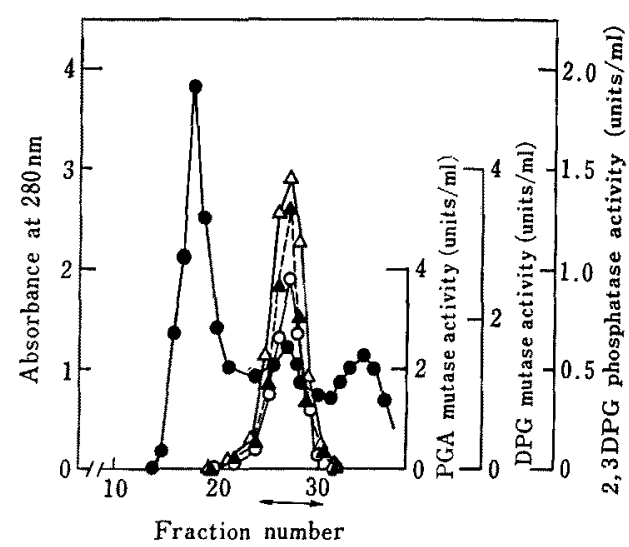

FIG. 2. Sephadex G-100 Chromatogram of the Second Peak Obtained by DEAE-Sephadex Chromatography.

- - absorbance at $280 \mathrm{~nm} ; \triangle-\triangle$, DPG mutase;

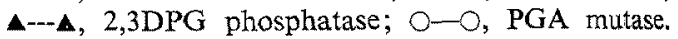
Enzyme activities are expressed as units $/ \mathrm{ml}$. $82 \mathrm{mg}$ of the second peak obtained by DEAE-Sephadex chromatography was applied. Fractions were $3 \mathrm{ml}$. The flow rate was $10 \mathrm{ml} / \mathrm{hr}$. The horizontal line with arrow heads indicates fractions pooled after elution. DPG mutase and 2,3DPG phosphatase activities were assayed with Assays $I .^{13)}$

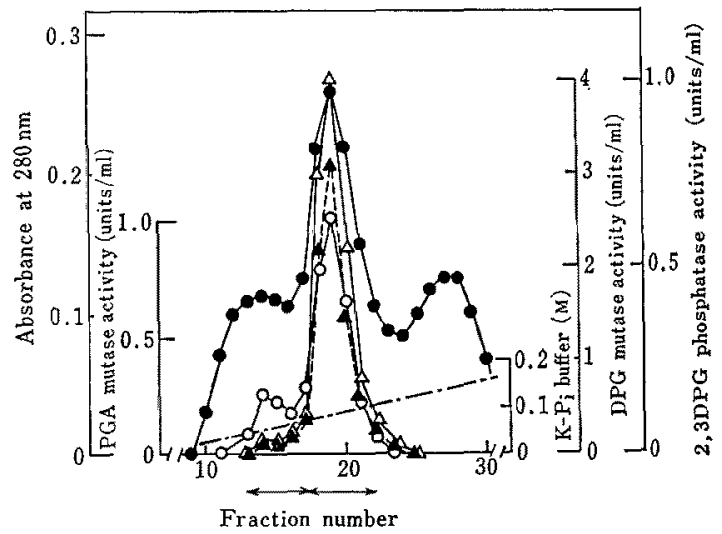

FIG. 3. Elution Profile from Hydroxylapatite.

- absorbance at $280 \mathrm{~nm} ; \triangle-\triangle$, DPG mutase; $\triangle--\Lambda, 2$, 3DPG phosphatase; $\bigcirc-O$, PGA mutase; -.-. concentration of potassium phosphate buffer. Enzyme activities are expressed as units $/ \mathrm{ml} .12 \mathrm{mg}$ of the protein purified by Sephadex $\mathrm{G}-100$ was applied. Fractions were $3.3 \mathrm{ml}$. The flow rate was $12 \mathrm{ml} / \mathrm{hr}$. The horizontal lines with arrow heads indicate fractions pooled after elution. Active fractions eluted early were designated peak II and those eluted later peak III. DPG mutase and 2,3DPG phosphatase were assayed using Assay $I$ and Assay $I I$, respectively. ${ }^{13)}$ 
gradient of potassium phosphate ranging from $10 \mathrm{~mm}$ to $200 \mathrm{~mm}$. Two peaks carrying the three enzyme activities in differing ratios were found (Fig. 3). The first peak, termed peak II in this paper, had $33 \%$ of the total PGA mutase activity recovered, while $67 \%$ of the activity appeared in the second peak, peak III. Although a great part of the DPG mutase and 2,3DPG phosphatase activities was recovered in peak III, peak II had these enzyme activities in detectable amounts.

CM-Sephadex chromatography of Peak $I$. To see if the three enzyme activities in peak I were chromatographically separable, peak I was further purified. To peak I was added solid ammonium sulfate to $75 \%$ saturation. The precipitate was dissolved in and dialysed against $5 \mathrm{mM}$ citrate buffer $\mathrm{pH} 6.0$ containing $0.1 \mathrm{~mm}$ EDTA, $5 \mathrm{~mm} \beta$-mercaptoethanol, and $1 \mathrm{mM}$ 2PGA. The dialysed solution was loaded on a CM-Sephadex C-50 column (2.7X $29 \mathrm{~cm}$ ) equilibrated with the same buffer. The three enzyme activities were not absorbable to CM-Sephadex and appeared in the flowthrough fractions (Data not shown).

\section{2,3DPG phosphatase in the presence and the absence of 2-phosphoglycolate}

As the 2, 3DPG phosphatase activity in pig erythrocytes is low, the activity has been measured throughout the purification steps in the presence of 2-phosphoglycolate, which has been shown to be a potent activator of the 2, 3DPG phosphatase activity manifested by 2 , 3DPG-dependent PGA mutase proteins from various sources. ${ }^{13,25,26}$ ) It seemed possible that there was a 2,3DPG phosphatase not being activated by 2-phosphoglycolate, but capable of breaking down 2, 3DPG in the pig erythrocytes. To test this possibility, the 2, 3DPG phosphatase activity in the presence and the absence of 2-phosphoglycolate was measured for samples from some purification iteps: hemolysate, ammonium sulfate fractionition, Sephadex G-100 chromatography, and he final preparation (peak III). The extent If activation was almost constant (450- to
500 -fold) throughout the purification, indicating that the 2, 3DPG phosphatase enhanced by 2-phosphoglycolate does indeed function in the 2, 3DPG metabolism of pig erythrocytes.

\section{Purity and size of enzyme}

Evidence that peak III is homogeneous was obtained by several methods.

The enzyme preparation displayed a sharp single band on polyacrylamide gel electrophoresis in the presence and the absence of sodium dodecylsulfate (Fig. 4 and Fig. 7 B).

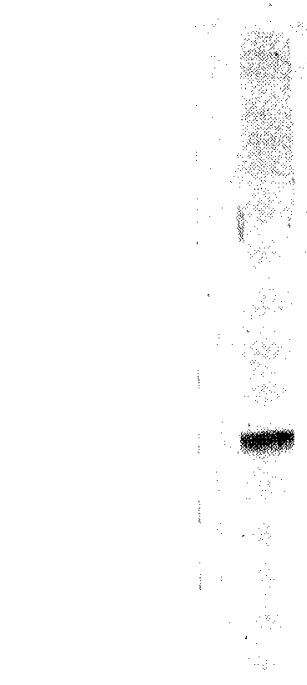

(A)
Fig. 4. Polyacrylamide Gel Electrophoresis of Peak III.

The proteins applied were $8 / \mathrm{g}$ (A) and $16 \mu \mathrm{g}$ (B). Migration is from top to bottom.

A single and symmetrical boundary with a $s_{20, \mathrm{w}}$ value of $4.0 \mathrm{~S}$ was observed on ultracentrifugation (Fig. 5).

The molecular weight of peak III was determined using the sedimentation equilibrium method. As shown in Fig. 6, a plot of the logarithm of fringe displacement versus the square of the radius gave an excellent straight line, indicating protein homogeneity. The molecular weight was calculated to be 59,000 . To investigate the subunit structure, peak III was subjected to polyacrylamide gel electrophoresis in the presence of sodium dodecyl- 


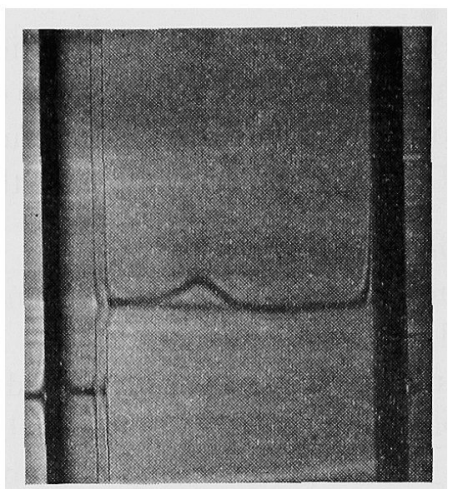

FIG. 5. Sedimentation Pattern of Peak III.

The protein was $3.9 \mathrm{mg} / \mathrm{ml}$ in buffer A containing $0.1 \mathrm{M}$ $\mathrm{KCl}$. Migration is from left to right. The photograph was taken 48 min after reaching a speed of $60,000 \mathrm{rev} . \mathrm{min}$. The schlieren plate angle was $55^{\circ}$.

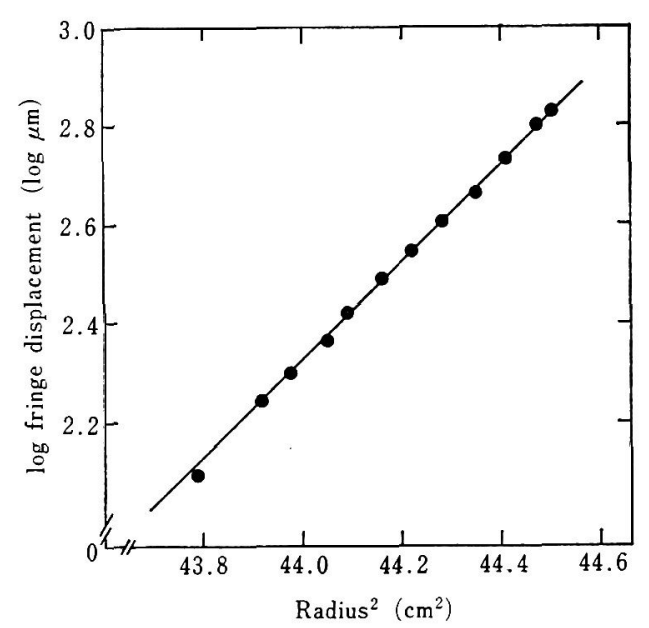

FIG. 6. Analytical Graph of the Sedimentation Equilibrium Pattern of Peak III.

There was $200 \mu \mathrm{g} / \mathrm{ml}$ protein in buffer A containing $0.1 \mathrm{M} \mathrm{KCl}$. The logarithm of the fringe displacement is plotted against the square of the radial position. Data were obtained from a picture taken with a Rayleigh interference optical system $9 \mathrm{hr}$ after reaching a speed of $26,000 \mathrm{rev} . / \mathrm{min}$.

sulfate (Fig. 7). The sample gave a single band, the molecular weight of which was calculated as 28,000 by use of a standard curve drawn from the electrophoretic mobilities of proteins of known molecular weight. Peak III, therefore, is composed of two subunits of similar molecular weight.

\section{Isoelectric focusing of Peak III}

Isoelectric focusing is a sensitive method for
(A)

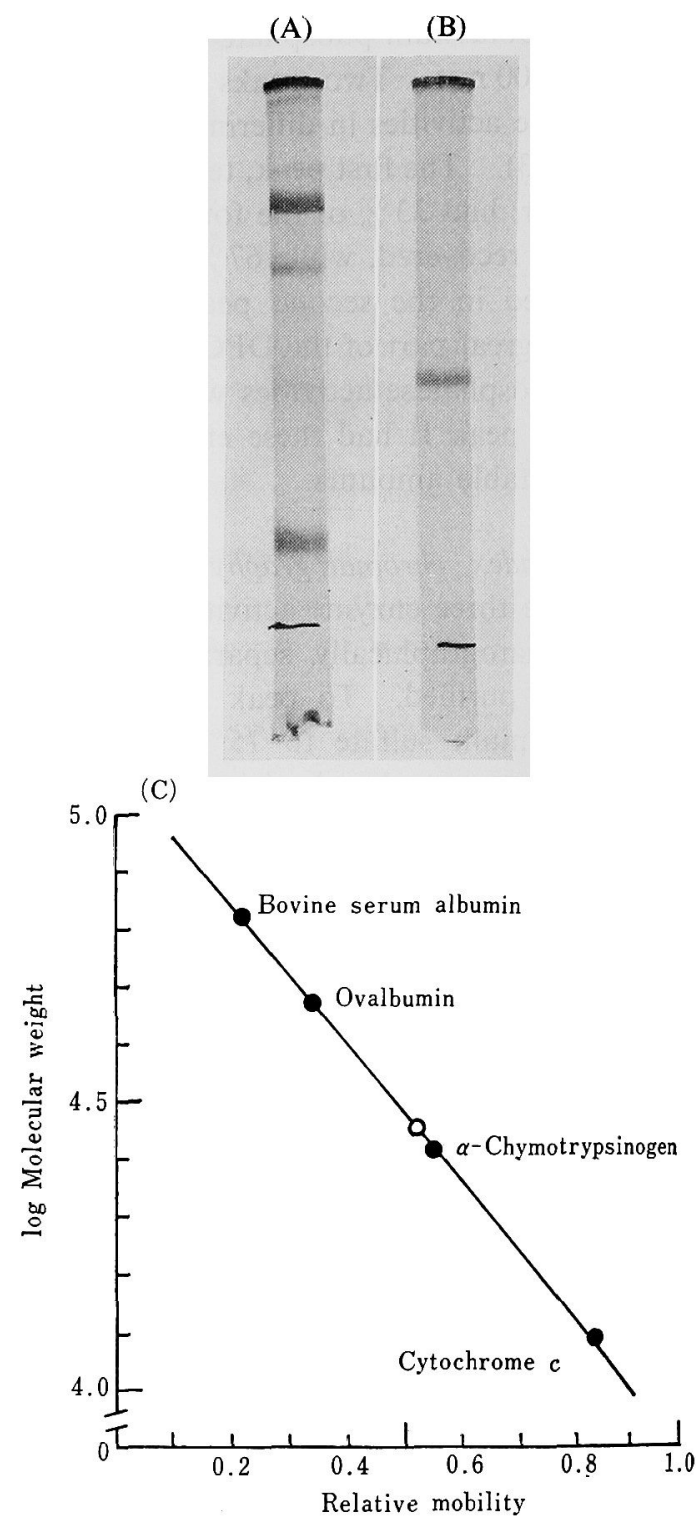

FIG. 7. Polyacrylamide Gel Electrophoresis of Peak III in the Presence of Sodium Dodecyl Sulfate.

(A) Standard (top to bottom) contain bovine serum albumin $(66,000)$, ovalbumin $(47,000), \alpha$-chymotrypsinogen $(26,000)$ and cytochrome $c(12,400)$. (B) Peak III $(10 \mu \mathrm{g})$. (C) Standard curve drawn from the mobilities of standard proteins.

- standard proteins; O, peak III.

separating proteins according to their electric charges. Peak III was subjected to isoelectric focusing to see if the three enzyme activities were distinguishable. The three activities sharply electrofocused at an isoelectric point of 5.1; other fractions showed no ensyme activity 

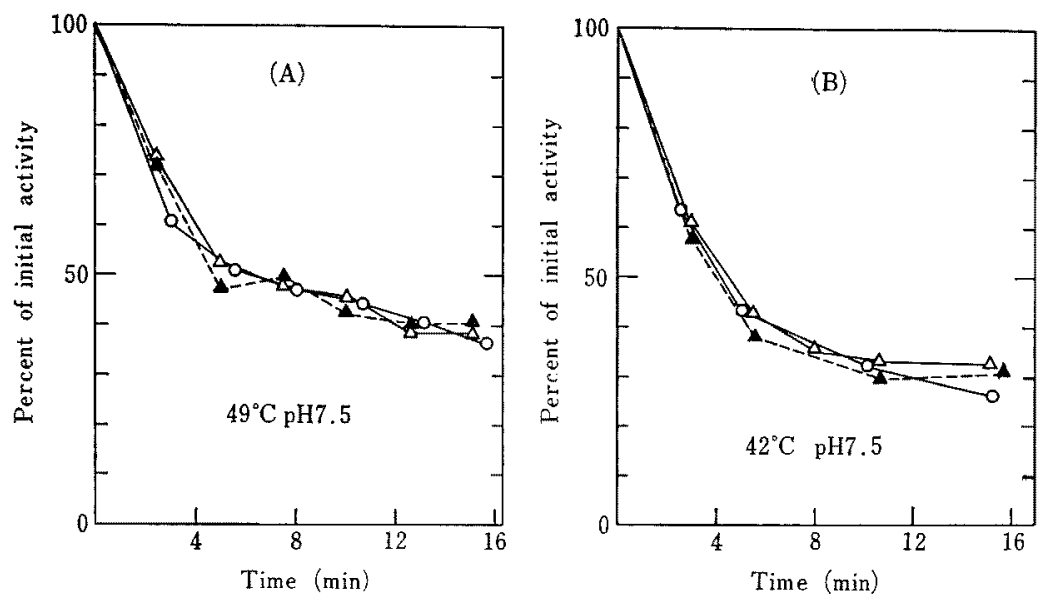

FIG. 8. Thermal Inactivation Curves of the Three Enzyme Activities of Peaks III and I.

(A) peak III. (B) peak I. $\triangle-\triangle$, DPG mutase; $\triangle--\Delta, 2,3 D P G$ phosphatase; -0, PGA mutase. The protein concentration of peak III was $216 \mu \mathrm{g} / \mathrm{ml}$ in buffer $\mathrm{A}$ and that of peak $1,1.5 \mathrm{mg} / \mathrm{ml}$. The sample solutions ( $2 \mathrm{ml}$ per each peak) were heated at the indicated temperatures and aliquots were removed at intervals to assay the three enzyme activities. DPG mutase and 2,3DPG phosphatase activities were assayed with Assays $I^{13)}$

(Data not shown).

\section{Thermal inactivation}

Evidence that the DPG mutase, 2, 3DPG phosphatase, and PGA mutase activities of peaks I and III are due to one protein is shown in Fig. 8; although peak I purified by CMSephadex chromatography was heterogeneous electrophretically, it also was subjected to thermal-inactivation experiments. In both cases the three enzyme activities were lost at the same rate during thermal inactivation, indicating that the activities are related to one protein.

\section{Enzymatic properties of Peak III}

Specific activity. Specific activities of the DPG mutase and 2,3DPG phosphatase of peak III from pig erythrocytes (Table I) were very similar to those of peak III from human erythrocytes, while the PGA mutase activity of the pig enzyme was lower.

Substrate specificity of the 2, 3DPG phosphatase activity of Peak III. Peak III was highly specific toward 2, 3DPG in hydrolyzing a phosphoester bond. 2-Phosphoglycolate, DL- $\alpha$-glycerophosphate, $\quad \beta$-glycerophosphate,
TABle II. EFFEct of Compounds on the 2, 3DPG Phosphatase and DPG MUtase Activities of PEAK III

2, 3DPG phosphatase was assayed with Assay $I$ using $0.4 \sim 100 \mu \mathrm{g}$ of peak III and DPG mutase was assayed with Assay $I I$ using $1 \mu \mathrm{g}$ of the enzyme. ${ }^{13}$ ) The reaction mixture for $2,3 \mathrm{DPG}$ phosphatase assay contained no 2-phosphoglycolate except when its effect was examined.

\begin{tabular}{|c|c|c|c|}
\hline Enzyme & Compounds & Concn. & $\begin{array}{l}\text { Relative } \\
\text { activity }\end{array}$ \\
\hline \multirow{13}{*}{$\begin{array}{l}2,3 \mathrm{DPG} \\
\text { phosphatase }\end{array}$} & & $\mathrm{mM}$ & \\
\hline & None & $\longrightarrow$ & 1.0 \\
\hline & 2PGA & 1.0 & 0.84 \\
\hline & 3PGA & 0.5 & 0.17 \\
\hline & HPAP & 0.02 & 31 \\
\hline & 2-Phospho- & & \\
\hline & glycolate & 0.05 & 500 \\
\hline & $\mathrm{KCl}$ & 100 & 0.94 \\
\hline & $\mathrm{NaHSO}_{3}$ & 20 & 3.4 \\
\hline & $\mathrm{KCl}+$ & 100 & \multirow{2}{*}{55} \\
\hline & $\mathrm{NaHSO}_{3}$ & 20 & \\
\hline & $\mathrm{NaCl}+$ & 100 & \multirow{2}{*}{50} \\
\hline & $\mathrm{NaHSO}_{3}$ & 20 & \\
\hline \multirow{7}{*}{ DPG mutase } & None & - & 1.0 \\
\hline & $2,3 \mathrm{DPG}$ & 0.1 & 0.4 \\
\hline & 2-Phospho- & & \\
\hline & glycolate & 0.4 & 0.4 \\
\hline & HPAP & 0.4 & 0 \\
\hline & $P_{\mathrm{i}}$ & 0.4 & 0.57 \\
\hline & $\mathrm{NaHSO}_{3}$ & 6.0 & 0.47 \\
\hline
\end{tabular}


2PGA, 3PGA, and G6P did not serve as substrates at a concentration of $0.5 \mathrm{~mm}$ (Data not shown). All of these compounds except 2phosphoglycolate were tested in the presence and the absence of 2-phosphoglycolate, a potent activator of 2, 3DPG phosphatase activity (see Table II).

Effects of compounds on the 2,3DPG phosphatase and DPG mutase activities of Peak III. The 2,3DPG phosphatase and DPG mutase activities of peak III were examined for the effects of various compounds shown to affect both activities of the enzyme from human erythrocytes. ${ }^{13)}$ As shown in Table II, monophosphoglycerates inhibited the 2,3DPG phosphatase activity, while 2-phosphoglycolate and HPAP markedly enhanced the activity. The effect of HPAP has not yet been tested on erythrocyte enzymes, but it has been shown to enhance the 2, 3DPG phosphatase activity of yeast PGA mutase. ${ }^{25)}$ Enhancement by 2-phosphoglycolate and HPAP seems to be a property of the 2, 3DPG phosphatase activity associated with 2,3DPG-dependent PGA mutases. ${ }^{13,25,26)}$ Bisulfite and $\mathrm{KCl}$ or bisulfite and $\mathrm{NaCl}$ together markedly enhanced the activity, while little effect was seen from the presence of $\mathrm{KCl}$ alone. The chlorine ion seems to be required for display of the stimulatory effect of bisulfite. The small activation observed in the presence of bisulfite alone is probably related to chlorine ions originating from the Tris-HCl buffer.

It has been shown that the inhibition of DPG mutase by its product, $2,3 \mathrm{DPG}$, is an efficient device for the regulation of 2,3DPG level in human erythrocytes. ${ }^{27)}$ The DPG mutase activity of peak III also suffers product inhibition (Table II). HPAP completely inhibits the activity at concentrations at which other phosphate compounds inhibited partially. It is interesting that compounds having a stimulatory effect on 2,3DPG phosphatase activity inversely inhibit DPG mutase activity.

\section{DISCUSSION}

The most remarkable result described here is that 2,3DPG synthesis and breakdown in pig erythrocytes are catalysed by one protein (peak III) carrying PGA mutase activity. This is supported by the experimental results that: (a) peak III had the bulk of the DPG mutase and 2,3DPG phosphatase activities in the hemolysates, (b) peak III was homogeneous by various criteria of protein purity, and (c) the three enzyme activities of peak III were lost at the same rate on thermal inactivation.

Striking resemblances in physical and enzymatic properties were observed between peaks III of human and of pig erythrocytes. ${ }^{13,14}$ Inverse effects of phosphate compounds on the 2, 3DPG phosphatase and DPG mutase activities of peak III from pig erythrocytes indicate that one active site on this protein molecule is related to both activities (see Table II). Further studies are needed, but it is likely that not only these two activities but also the PGA mutase activity are manifested at one active site, as are those of the enzyme from human erythrocytes. ${ }^{13,14)}$ Results from both erythrocytes support the suggestion that 2,3DPG levels in mammalian erythrocytes rich in this compound may be regulated by one multifunctional protein capable of catalysing the two irreversible reactions responsible for the metabolism of 2,3DPG. A possible significance for multifunctionality has been suggested for the 2, 3DPG metabolism of human

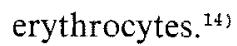

Results of thermal inactivation-experiments on peak I indicate that it also is a multifunctional enzyme. However, peak I probably functions as PGA mutase in glycolysis, as its 2,3DPG-metabolizing activities are very low compared with those of peak III.

It appears from the low activities of the three enzymes in peak II that this peak contributes neither to glycolysis nor to 2,3DPG metabolism. Such a peak has been found in human erythrocytes. ${ }^{13}$ ) Although little is known of peak II, it is a tempting assumption that this peak might be a intermediate of an interconversion between peaks I and III.

The results described in this paper support 
the hypothesis of a previous paper ${ }^{19}$ that 2, 3DPG-dependent PGA mutase generally possesses the DPG mutase and 2,3DPG phosphatase activities.

\section{REFERENCES}

1) S. Rapoport and G. M. Guest, J. Biol. Chem., 129, 781 (1939).

2) G. R. Bartlett, ibid., 234, 449 (1959).

3) A. Chanutin and R. R. Curnish, Arch. Biochem. Biophys., 121, 96 (1967).

4) R. Benesch and R. E. Benesch, Biochem. Biophys. Res. Commun., 26, 162 (1967).

5) A. Askari and S. N. Rao, Biochim. Biophys. Acta, 151, 198 (1968).

6) R. Sasaki, K. Ikura, S. Katsura and H. Chiba, Agr. Biol. Chem., 40, 1797 (1976).

7) J. A. Black and M.H. Henderson, Biochim. Biophys. Acta, 284, 115 (1972).

8) G. J. Brewer, ibid., 192, 157 (1969).

9) Z. Dische and D. Igals, Arch. Biochem. Biophys., 101, 489 (1963).

10) A. Hershko, A. Razin and J. Mager, Biochim. Biophys. Acta, 184, 64 (1969).

11) S. K. Srivastava and E. Beutler, Arch. Biochem. Biophys., 148, 249 (1972).
12) L. C. Yip and M. E. Balis, Biochem. Biophys. Res. Commun., 63, 722 (1975).

13) R. Sasaki, K. Ikura, E. Sugimoto and H. Chiba, Eur. J. Biochem., 50, 581 (1975).

14) K. Ikura, R. Sasaki, H. Narita, E. Sugimoto and H. Chiba, ibid., 66, 515 (1976).

15) R. Rosa, I. Audit and J. Rosa, Biochimie, 57, 1059 (1975).

16) L. F. Hass and K. B. Miller, Biochem. Biophys. Res. Commun., 66, 970 (1975).

17) W. Kiessling, Ber. Chem. Ges., 68, 243 (1935).

18) G. R. Bartlett, J. Biol. Chem., 234, 459 (1959).

19) R. Sasaki, S. Utsumi, E. Sugimoto and H. Chiba, Eur. J. Biochem., 66, 523 (1976).

20) H. Chiba and E. Sugimoto, Bull. Agr. Chem. Soc. Japan, 23, 207 (1959).

21) R. Sasaki, E. Sugimoto and H. Chiba, Arch. Biochem. Biophys., 115, 53 (1966).

22) E. J. Davies, Ann. N. Y. Acad. Sci, 121, 404 (1964).

23) K. Weber and M. Osborn, J. Biol. Chem., 244, 4406 (1969).

24) D. A. Yphantis, Biochemistry, 3, 297 (1964).

25) R. Sasaki, M. Hirose, E. Sugimoto and H. Chiba, Biochim. Biophys. Acta, 227, 595 (1971).

26) Z. B. Rose and J. Liebowitz, J. Biol. Chem., 245, 3232 (1970).

27) Z. B. Rose, ibid., 243, 4810 (1968). 